\title{
Zonasi Lanskap Ekowisata Pesisir Kecamatan Paloh Kalimantan Barat
}

\author{
SABAHAN ${ }^{*}$, ROSSI EVITA²
}

1. Program Studi Manajemen Bisnis, Pariwisata, Politeknik Negeri Sambas, Kabupaten Sambas, Kalimantan Barat 79462, Indonesia

2. Pusat Penelitian dan Pengabdian Kepada Masyarakat, Politeknik Negeri Sambas, Kabupaten Sambas, Kalimantan Barat 79462, Indonesia

*E-mail: sabahan_polteksbs@yahoo.com

\section{ABSTRACT \\ Coastal Landscape Zoning of Ecotourism in Paloh District, West Kalimantan}

Paloh district is one of the coastal areas in the Sambas regency and is the only subdistricts in Kalimantan Barat Province bordering direct terrestrial and aquatic with neighboring Malaysia. With a long coastline of $63 \mathrm{~km}$ (32\% of the total length of the beach Sambas) and the various resources they have, then the Sambas district has great opportunities in coastal tourism development. The existence of the sprawling beach and geographical districts Paloh directly adjacent to neighboring Malaysia will indicate the magnitude of the potential of eco-tourism sector in the region. Coastal ecosystems that are different from other areas with the structure of white sand that almost stretches along the coastline, the condition of sea water is clean (clear), the existence of mangrove forests and habitat for diverse species of turtles, fish, and a wealth of other biodiversity can be an attraction of ecotourism its own for this region. The purpose of this study was to analyze the object / eco-tourism attraction and draw up zoning tourist area. Data needed in this research is the layout, aesthetics and authenticity, transport and aksessibilitas, attractions and uniqueness, support facilities, availability of clean water, and community support. Methods of data collection is done by interviews, library research and field surveys. Based on the results of the assessment has been done, that the coastal areas Paloh districts actually have six $(60 \%)$ of the object / eco-tourism attraction with considerable potential category (S2) and 4 (40\%) object / eco-tourism attraction with less potential category (S3). Direction of development of ecotourism in the district Paloh zone can be divided into four development zones, namely: Zone I: As the allotment of service to visitors that will be developed a lot of facilities supporting the tour here. In addition, this region is focused as cultural tourism area. Zone II: As an ecotourism area classification of the types of activities and facilities are limited and the tourist sites of conservation as well as a buffer zone for ecotourism in the district Paloh. Zone III: This region is a region devoid of inhabitants who 
are on the border of two villages of Sebubus and Temajuk that made intensive tourist area. Zone IV: This area is located in the village Temajuk and become a hub for residential Temajuk villagers who also serve as ecotourism those classified as intensive.

Keywords: Coastal area, landscape, zoning, ecotourism, district Paloh

\section{Pendahuluan}

Pengembangan ekowisata yang baik didasarkan atas sistem pandang yang mencakup didalamnya prinsip kesinambungan dan pengikutsertaan masyarakat setempat dalam proses pengembangan ekowisata tersebut. Ekowisata berbasis masyarakat (Community-Based Ecotourism) merupakan usaha ekowisata yang menitikberatkan peran aktif komunitas. Hal tersebut didasarkan kepada kenyataan bahwa masyarakat memiliki pengetahuan tentang alam serta budaya yang menjadi potensi dan nilai jual sebagai daya tarik wisata, sehingga pelibatan masyarakat menjadi mutlak (Departemen Kebudayaan dan Pariwisata, 2009).

Kecamatan Paloh merupakan salah satu wilayah pesisir di kabupaten Sambas dan merupakan satu-satunya kecamatan di Kalimantan Barat yang berbatasan langsung secara terestrial dan akuatik dengan negara tetangga Malaysia. Dengan panjang garis pantai $63 \mathrm{~km}$ (32\% dari total panjang pantai kabupaten Sambas) dan berbagai sumber daya yang dimiliki, maka kabupaten Sambas mempunyai peluang besar dalam pengembangan ekowisata pesisir.

Keberadaan pantai yang terbentang luas dan letak geografis kecamatan Paloh yang berbatasan langsung dengan negara tetangga Malaysia mengindikasikan akan besarnya potensi sektor ekowisata di wilayah tersebut. Ekosistem pesisir pantai yang berbeda dari daerah lainnya dengan struktur pasir puth yang hampir terbentang sepanjang garis pantai, kondisi air lautnya yang bersih (jernih), keberadaan hutan mangrove dan habitat beragam jenis satwa penyu, ikan, dan kekayaan keanekaragaman hayati lainnya dapat menjadi daya tarik ekowisata tersendiri bagi wilayah ini.

Namun, di tengah berbagai potensi ekowisata yang dimiliki, sektor ekowisata masih belum berkembang sehingga tidak memberikan dampak signifikan terhadap pelestarian lingkungan dan kesejahteraan masyarakat di wilayah ini. Oleh sebab itu penelitian ini diperlukan dengan tujuan :1) mengidentifikasi dan menganalisis sumber daya ekowisata pesisir di kecamatan Paloh; 2) menganalisis keikutsertaan masyarakat dalam kegiatan ekowisata pesisir di kecamatan Paloh; 3) menyusun onasi lanskap kawasan ekowisata pesisir di kecamatan Paloh.

\section{Metode Penelitian}

\subsection{Kerangka Analisis}

Untuk membuat sebuah perencanaan lanskap kawasan ekowisata harus diketahui terlebih dahulu potensi sumber daya alam, budaya masyarakat setempat, arah pengelolaan kawasan dan fasilitas pendukung yang ada. Data sumber daya ekowisata yang dikumpulkan meliputi potensi objek/atraksi, fisik kawasan, dan sosial budaya. Data 
potensi masyarakat yang dukumpulkan berupa partisipasi dan keinginan masyarakat terhadap usaha pengembangan ekowisata. Data ini selanjutnya dianalisis untuk menentukan objek/atraksi, jalur sirkulasi, aktivitas, dan fasilitas di kawasan yang akan dikembangkan.

Analisis yang dilakukan dalam penelitian ini meliputi analisis terhadap objek dan atraksi wisata, serta zonasi area wisata di kecamatan Paloh. Informasi tentang sumber daya wisata dianalisis dalam rangka untuk menilai sejauh mana potensi wisata yang dimiliki yang kemudian dijadikan dasar dalam menentukan konsep dan arah pengembangan lanskap kawasan ekowisata pesisir di kecamatan Paloh.

\subsection{Waktu dan Lokasi Penelitian}

Penelitian yang meliputi tahapan persiapan hingga konsep dan perencanaan serta pelaporan dilakukan selama 10 (Sepuluh) bulan. Penelitian ini dilakukan di kabupaten Sambas propinsi Kalimantan Barat dengan fokus lokasi penelitian pada kawasan pesisir kecamatan Paloh yang merupakan wilayah yang berbatasan langsung dengan distrik Sematan Negara Malaysia bagian Timur.

\subsection{Pengumpulan dan Analisis Data}

Pendekatan yang digunakan dalam penelitian ini adalah metode deskriptif kualitatif dengan teknik pengumpulan data yang digunakan adalah studi pustaka, wawancara, partisipasi, dan survei lapangan. Pengumpulan dan analisis data sesuai dengan masingmasing tujuan dalam penelitian ini diringkas dalam tabel 1.

Tabel 1. Pengumpulan dan Analisis Data Sesuai Tujuan Penelitian

\begin{tabular}{|c|c|c|c|c|}
\hline No & $\begin{array}{c}\text { Tujuan } \\
\text { Penelitian }\end{array}$ & Data & $\begin{array}{c}\text { Metode } \\
\text { Pengumpulan } \\
\text { Data }\end{array}$ & $\begin{array}{c}\text { Teori/standar } \\
\text { yang digunakan }\end{array}$ \\
\hline 1 & $\begin{array}{l}\text { Menganalisis } \\
\text { objek/atraksi } \\
\text { ekowisata }\end{array}$ & $\begin{array}{l}\text { Letak, estetika dan } \\
\text { keaslian, transportasi dan } \\
\text { aksessibilitas, atraksi dan } \\
\text { keunikan, fasilitas } \\
\text { pendukung, ketersediaan } \\
\text { air bersih, dan dukungan } \\
\text { masyarakat }\end{array}$ & $\begin{array}{l}\text { - Wawancara } \\
\text { - Studi pustaka } \\
\text { - Survei lapang }\end{array}$ & 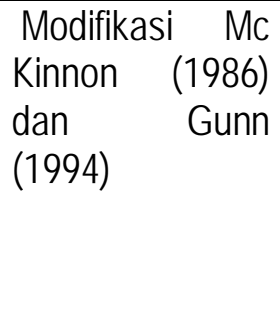 \\
\hline 2 & $\begin{array}{l}\text { Menyusun } \\
\text { zonasi } \\
\text { wisata }\end{array}$ & $\begin{array}{l}\text { Hasil analisis data yang } \\
\text { telah dilakukan }\end{array}$ & $\begin{array}{l}\text { - Wawancara } \\
\text { - Studi pustaka } \\
\text { - Survei lapang }\end{array}$ & $\begin{array}{l}\text { Analisis } \\
\text { perencanaan } \\
\text { lanskap }\end{array}$ \\
\hline
\end{tabular}

\section{Hasil Dan Pembahasan}

\subsection{Analisis Objek dan Atraksi Wisata}

Adanya objek wisata di kawasan pesisir kecamatan Paloh memiliki pembeda khas dengan objek wisata di daerah lainnya. Objek wisata tersebut memiliki keunikan dan karakteristik serta atraksi wisata yang menarik sehingga dapat mendorong minat wisatawan untuk berkunjung ke kawasan wisata ini. 
Keunikan yang ada dapat menarik minat wisatawan untuk berkunjung ke kawasan wisata ini. Berdasarkan hasil penilaian yang telah dilakukan, bahwa wilayah pesisir kecamatan Paloh secara aktual memiliki 6 (60\%) objek/atraksi ekowisata dengan kategori cukup potensial (S2) dan 4 (40 \%) objek/atraksi ekowisata dengan kategori kurang potensial (S3), seperti tampak pada Tabel 2.

Tabel 2. Penilaian Kelayakan Objek dan Atraksi Wisata di Kecamatan Paloh

\begin{tabular}{|c|c|c|c|c|c|c|c|c|c|c|}
\hline \multirow{2}{*}{$\begin{array}{l}\mathrm{N} \\
0 .\end{array}$} & \multirow{2}{*}{$\begin{array}{l}\text { Objek/Atraksi } \\
\text { Wisata }\end{array}$} & \multicolumn{7}{|c|}{ Parameter Kelayakan } & \multirow[b]{2}{*}{ Skor } & \multirow[b]{2}{*}{ Kategori } \\
\hline & & 1 & 2 & 3 & 4 & 5 & 6 & 7 & & \\
\hline 1 & Pantai Tanah & 3 & 1 & 25 & 2 & 2 & 3 & 3 & 185 & S2 \\
\hline 2 & Hutan Mangrove & 3 & 1 & 9 & 9 & 2 & 2 & 3 & 148 & S2 \\
\hline 3 & Pantai Selimpai & 2 & 2 & 32 & 2 & 8 & 1 & 3 & 157 & $\mathrm{~S} 2$ \\
\hline 4 & Pantai Tanjung & 2 & 2 & 25 & 1 & 1 & 1 & 3 & 158 & $\mathrm{~S} 2$ \\
\hline 5 & Pantai Sungai & 8 & 2 & 24 & 8 & 1 & 8 & 3 & 120 & S3 \\
\hline 6 & Pantai Tanjung & 8 & 2 & 16 & 8 & 2 & 8 & 3 & 120 & S3 \\
\hline 7 & Pantai Bayuan & 8 & 2 & 24 & 8 & 1 & 8 & 3 & 120 & S3 \\
\hline 8 & Pantai Camar & 8 & 2 & 17 & 8 & 8 & 8 & 3 & 105 & S3 \\
\hline 9 & Pantai Mauludin & 8 & 2 & 27 & 1 & 3 & 8 & 3 & 149 & $\mathrm{~S} 2$ \\
\hline 10 & Tanjung Datok & 8 & 3 & 32 & 1 & 3 & 8 & 3 & 154 & $\mathrm{~S} 2$ \\
\hline
\end{tabular}

Keterangan:

1. Letak dari jalan utama

2. Estetika dan keaslian

3. Atraksi

4. Fasilitas Pendukung

5. Ketersediaan air

6. Transportasi dan aksessebilitas

7. Dukungan masyarakat

Nilai penjumlahan skoring penilai $(n=8)$

S1 = Sangat Potensial (nilai $193-256$ )

S2 = Cukup Potensial (nilai 129 - 192)

S3 = Kurang Potensial (nilai $65-128$ )

$\mathrm{N}=$ Tidak Potensial (nilai $\leq 64$ )

\subsection{Pemetaan Partisipatif}

Pemetaan partisipatif yang dilakukan memberikan gambaran bahwa masyarakat di lokasi penelitian mempunyai harapan besar terhadap usaha pengembangan kawasan ekowisata. Masyarakat yang tergabung dalam kelompok pemetaan partisipatif melakukan interpretasi peta yang di dalamnya memuat objek/atraksi wisata, aktivitas, fasilitas, dan jalur sirkulasi yang menghubungkan antar desa dan objek/atraksi wisata.

Berdasarkan gambaran pemetaan partisipatif ini, sesuai dengan pembagian zona wilayah pesisir kecamatan Paloh yang telah dilakukan maka dapat digambarkan bahwa 
pada zona I merupakan zona yang terfokus pada peruntukan pelayanan pengunjung dimana pada zona ini menyediakan banyak fasilitas penunjang wisata. Kawasan ini juga dijadikan sebagai pusat kawasan wisata budaya. Zona II merupakan kawasan yang diplot sebagai kawasan wisata konservasi hutan mangrove dan habitat penyu sehingga masyarakat berharap agar aktivitas wisata di sini dibatasi. Sedangkan zona III dan IV diperuntukkan sebagai kawasan ekowisata yang bersifat intensif. Aktivitas wisata yang direkomendasikan disini diantaranya memancing, berenang, dan bersampan yang didukung oleh berbagai fasilitas.

\subsection{Konsep Pengembangan Ekowisata}

Wilayah perbatasan kecamatan Paloh tergolong daerah tertinggal dengan sumber daya manusia yang kapasitas dan kualitasnya relatif rendah sebagai dampak dari terbatasnya infrastruktur sosial dan komunikasi. Selain kurangnya pelibatan masyarakat, keterbatasan infrastruktur sosial dan komunikasi ini juga yang mengakibatkan belum berkembangnya sektor ekowisata di wilayah ini. Padahal jika dilihat dari potensi alam terestrial dan akuatik yang dimiliki, wilayah ini sangatlah berpotensi untuk lebih maju dan berkembang. Konsep perencanaan pengembangan ekowisata di kecamatan Paloh adalah ekowisata pesisir berbasis masyarakat dimana pengembangan wisata didasarkan pada potensi lingkungan dan masyarakat untuk melindungi sumber daya alam dan kualitas lingkungan serta dapat menciptakan kesejahteraan masyarakat lokal. Konsep yang dikembangkan tersebut mengacu pada hasil analisis terhadap objek dan atraksi wisata, kesesuaian dan daya dukung kawasan serta akseptibilitas dan pemberdayaan masyarakat sehingga diharapkan mampu memenuhi kebutuhan wisatawan dan dapat menciptakan kesejahteraan masyarakat di kecamatan Paloh.

Konsep pengembangan aktivitas, fasilitas, dan jalur sirkulasi wisata didasari oleh keterhubungan ketiganya dalam pengembangan kawasan ekowisata sehingga ketiganya dianggap sebagai satu kesatuan yang utuh. Penggalian potensi wisata yang dimiliki untuk dapat terus menampilkan objek dan atraksi wisata yang menarik bagi wisatawan sangatlah perlu untuk dilakukan sehingga perencanaan dan pengembangan aktivitas, fasilitas, dan jalur sirkulasi wisata dapat memenuhi kebutuhan wisatawan. Jalur sirkulasi yang direncanakan diharapkan dapat mengarahkan dan memberikan kenyamanan bagi wisatawan. Selain itu jalur sirkulasi juga diharapkan dapat memberikan pengalaman dan gambaran ekowisata termasuk di dalamnya pengetahuan terhadap kehidupan masyarakat lokal.

Arah pengembangan zona ekowisata di kecamatan Paloh dapat dipilah menjadi empat zona pengembangan, yaitu:

Zona I: Sebagai peruntukan pelayanan terhadap pengunjung sehingga akan dikembangkan banyak fasilitas penunjang wisata di sini. Selain itu kawasan ini juga difokuskan sebagai kawasan wisata budaya.

Zona II: Sebagai kawasan ekowisata yang memiliki klasifikasi jenis aktivitas dan fasilitas yang terbatas dan merupakan lokasi wisata konservasi sekaligus sebagai zona penyangga bagi kawasan ekowisata di kecamatan Paloh. 
Zona III: Kawasan ini merupakan kawasan tanpa penghuni yang berada di perbatasan dua desa yaitu desa Sebubus dan Temajuk yang dijadikan kawasan wisata yang bersifat intensif.

Zona IV: Kawasan ini berada di desa Temajuk dan menjadi pusat lokasi pemukiman masyarakat desa Temajuk yang juga dijadikan sebagai kawasan ekowisata yang berklasifikasi intensif.

Agar kawasan ekowisata di kecamatan Paloh dapat berfungsi dengan baik, maka perkembangan kegiatan ekowisata haruslah diiringi dengan penataan lanskap kawasan ekowisata yang baik pula. Berdasarkan hasil analisis yang dilakukan, maka dikembangkan rencana pembagian ruang (zonasi) kawasan ekowisata pesisir di kecamatan Paloh kabupaten Sambas seperti yang terlihat pada gambar 1.

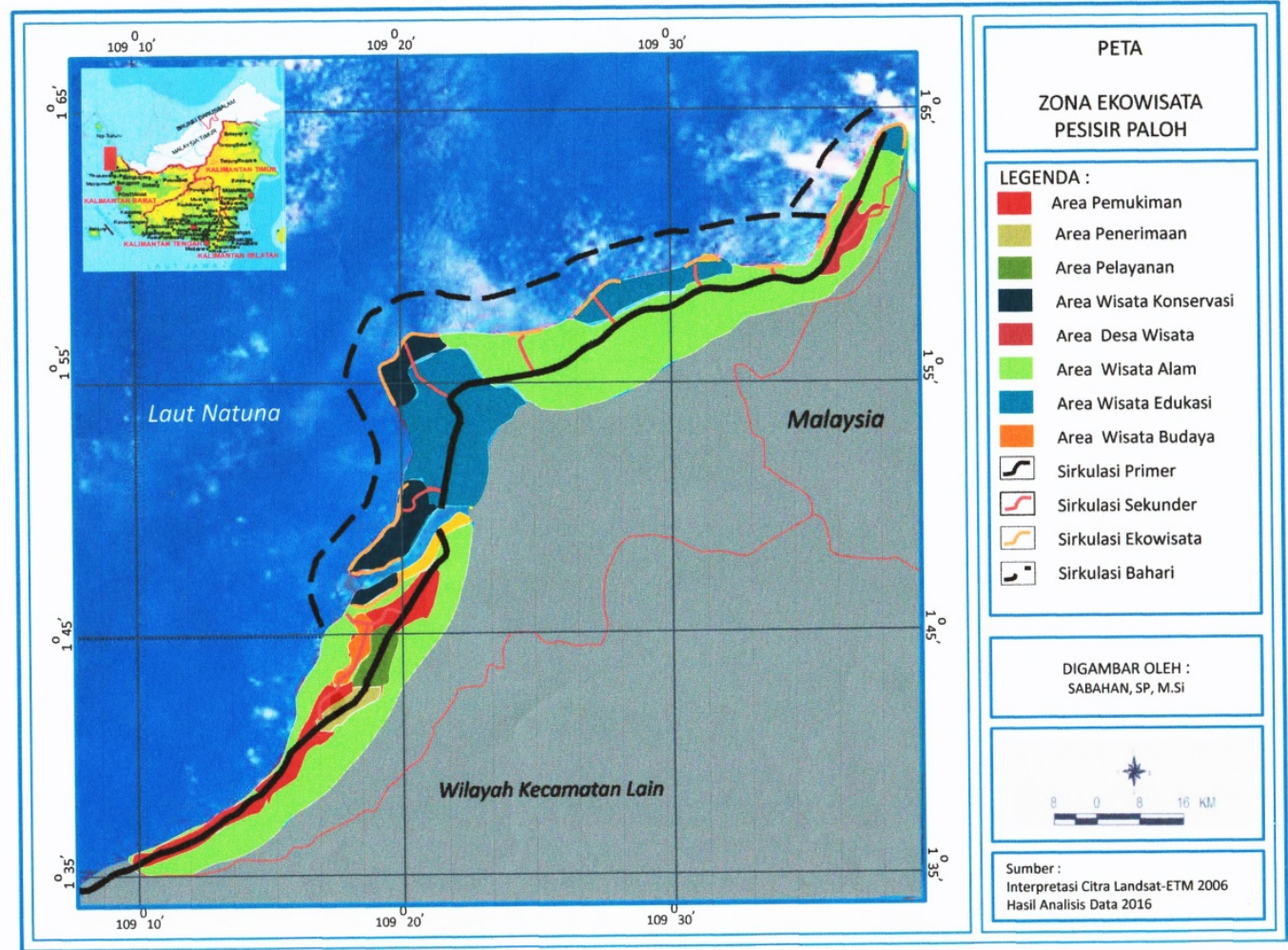

Gambar 1. Rencana Pembagian Ruang (Zonasi) Kawasan Ekowisata Pesisir

\section{Simpulan Dan Saran}

\subsection{Simpulan}

1. Kawasan pesisir kecamatan Paloh memiliki potensi yang cukup besar untuk dikembangkan sebagai kawasan ekowisata, namun secara aktual kawasan ini belum dikelola dengan baik sehingga masih kurang berkembang.

2. Mengingat kurangnya pelibatan masyarakat dalam usaha pengembangan kawasan ekowisata di kecamatan Paloh selama ini, maka konsep pengembangan yang dianggap tepat untuk diterapkan dalam pengembangan kawasan ekowisata di kecamatan Paloh adalah konsep pengembangan kawasan ekowisata pesisir berbasis masyarakat. 


\subsection{Saran}

1. Kecamatan Paloh memiliki potensi wisata yang cukup tinggi sehingga perlu adanya kebijakan pemerintah daerah untuk dapat menjadikan wilayah ini sebagai kawasan ekowisata pesisir dengan arahan pengembangan ekowisata yang lebih memperhatikan perlindungan alam dan pelestarian budaya, serta adanya pembinaan bagi masyarakat ke arah masyarakat wisata untuk dapat lebih meningkatkan peran serta masyarakat dalam penyelenggaraan ekowisata.

2. Kurang memadainya prasarana dan sarana penunjang wisata di kecamatan Paloh saat ini menuntut stakeholders wisata mendukung secara moril maupun materil dalam usaha pengembangan kawasan ekowisata di wilayah ini.

3. Perlu adanya penelitian lebih lanjut untuk dapat menggali potensi sumber daya wisata akuatik kecamatan Paloh terutama di perairan dari desa Sebubus sampai dengan desa Temajuk yang akan melengkapi pengembangan ekowisata pesisir berbasis masyarakat di kecamatan Paloh.

\section{Daftar Pustaka}

Badan Koordinasi dan Survei Pemetaan Nasional. 1996. Pengembangan Prototipe Wilayah Pesisir Dan Lautan Kupang Nusa Tenggara Timur. Pusbina-Inderasig Bakosurtanal, Cibinong.

Biro Pusat Statistik Kabupaten Sambas. 2015. Kecamatan Paloh dalam Angka. Sambas : BPS.

Gunn, C.A. 1994. Tourism Planning. Basics Concepts Cases. Washington: Tailor and Francis.

Lindberg, Kreg, and D. E. Hawkins. 1993. Ecotourism: A guide for Planners and Manager, The Ecotourism Society. North Bennington.

The International Ecotourism Society. 2008. TIES Global Ecotourism Fact Sheet. Washington DC, USA.

World Tourism Organization. 2005. Tourism 2020 Vision : East Asia And Pacific. Madrid, Spain. 